A REVIEW ON PHYTOCHEMICAL, MEDICINAL AND TRADITIONAL USES OF ACACIA SPECIES

\title{
PATEL $V^{1}$ AND GIRI SG ${ }^{2 *}$
}

1: M. Sc. Microbiology, Parul University of Applied Science, Parul University, Limbda, Waghodia Road, Vadodara-390025, Gujarat

2: Assistant Professor, Microbiology, Parul University of Applied Science, Parul University, Limbda, Waghodia Road, Vadodara-390025, Gujarat

*Corresponding Author: Sucheta Ghorai Giri: E Mail: suchetaghorai@gmail.com

Received $4^{\text {th }}$ June 2020; Revised $7^{\text {th }}$ July 2020; Accepted $5^{\text {th }}$ Aug. 2020; Available online $1^{\text {st }}$ April 2021

\section{https://doi.org/10.31032/IJBPAS/2021/10.4.5431}

ABSTRACT

Acacia species are widely known for their medicinal and traditional properties also used as alternatives against conventional medicines. The bioactive compounds and herbal extracts can be utilized to develop novel drugs against pathogenic organisms and to cure disease. Phytochemical present in different parts of plant are of great interest used by pharmaceuticals which have commercialized value. There is an increased demand of such chemicals to reenhance drugs throughout world. Sustainability of such medicinal plants against scientific medicine is catching scientist eyeball to implement such therapeutics for developing nations. Tannins, Glycosides, Saponins, Flavonoids and various other phytochemicals are already used to treat medical ailments. The current review work describes phytochemical constituents, traditional and medicinal uses of plants belonging to genus acacia.

Keywords: Genus Acacia, Phytochemical, Anti-cancer, Hepatoprotective, Type-2

\section{diabetes, Anti-crustacean, Antivenin, Antimalarial}

\section{INTRODUCTION}

Bacterial evolution is uncertain and disease control, April 2013). Increase in development of resistance is unpredictable [1]. Over use of antibiotics drives evolution of resistance in microorganisms (Centre for development of multidrug resistant bacteria have less susceptibility to antibiotics which develop problems and adds urgency to 
develop new strategies to fight infections

[2]. Use of antibiotics and drugs in clinical, medicine, agriculture promote development of resistance among microbial strains and causes serious problem in treatment of pathogenic microbial disease, hence it is necessary to search for new agents or alternative of antibiotic that are better and without any side effects treating disease. According to World Health Organization (2011), medicinal plants would be the best source to obtain variety of drugs. About $80 \%$ of individuals from developed countries use traditional medicines, which have compounds derived from medicinal plants [3]. Medicinal plants have been used as traditional source to treat numerous human diseases. Herbs have medicinal property due to presence of different active components such as alkaloids, steroids, volatile essentials oil, glycosides, resins, oleoresins, tannins, terpenes, phenols [4]. Phytochemicals are naturally present in the medicinal plants, leaves, roots and vegetables that are used to treat various diseases. Phytochemicals are primary and secondary compound. Proteins, carbohydrates and chlorophyll are primary constituents and terpenoids, alkaloids and phenolic compound are secondary constituents [5]. Most of the plant exhibit antibacterial, anti-fungal, antiinflammatory, vasoconstrictor actions, antihypersensitivity, anti-plasmodic activities, inhibitory effect against bacteria, pathogens, viruses etc [6]. The Ayurveda system of medicine uses about 700 species, Unani 700, Siddha 600 and modern medicine around 30 species of plant [7]. Plant based medicine are widely used in different countries.

Acacia are found in wild, they are shrubs and trees which belong to genus polyphyletic. Family is Fabaceae and the class of subfamily Mimosoideae. In 1773 Carl Linnaeus designated and described Acacia. The leaves of these plants contain tannins, utilized in pharmaceuticals and used as preservatives. The genus Acacia is second largest genus in Fabaceae family with 1300 species, about 960 of them native to Australia and rest of spread around tropical and subtropical regions of the word. Different regions in India use Acacia species for treatment of various ailments [8]. Acacia species contain bioactive resources such as flavonoids, alkaloids, phenolics, saponins, polysaccharides, tannins and terpenoids [9]. Different species of Acacia have medicinal importance but prominent ones are Acacia polyacantha, Acacia leucophal, Acacia nilotica, Acacia farnesiana, Acacia leucocephala, Acacia sinuate, Acacia ferruginea, Acacia catechu.

The present review covers some important plants belonging to the acacia genus with 
phytochemical constituents, medical and traditional use.

\section{A. Acacia catechu}

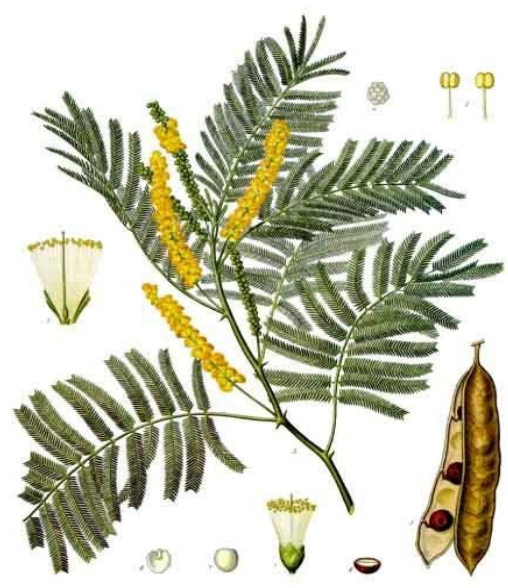

Figure 1

Acacia catechu belongs to Fabaceae family also called legume family or pea family due to presence of single chambered legume in all species of this family. Their size range from small to moderate and widely found in Asian countries. The main origin of this plant is India, Pakistan, Thailand and Bangladesh [10]. Acacia catechu is also known as kattha in (urdu), khadir (Hindustani and Punjabi), khoyer (Bengali and Assamese), khair and babul (Hindi), kaath (Marathi), and kachu (malay) [11].

\section{Botanical description\& Phytochemical properties.}

Acacia catechu is also known as black catechu. Acacia word originated from Greek word "Thorns" meaning "point or a barb". The species name is derived from word 'cutch' which is a tanning extract obtained from heartwood of Acacia catechu. Plant size is small to moderate about 15m height. Bark greyishbrown [10].
Acacia catechu has thorns (deciduous) height range from 12-13 meters. Katha is gummy compound which is released from woods. Pods contain 4-10 seeds. Leaves of Catechu show bi-pinnate structure and their leaflets are in the pairs of 30 to 50. In between the rachis main rachis pubescent. Fruits display brown pods flattened narrow at base. Size of flowers is between 5 to 10 $\mathrm{cm}$ present in axillary spikes [12] B.Ramesh conducted qualitative phytochemical analysis of Acacia catechu $\&$ identified the presence of primary metabolites such carbohydrates $(756 \mu \mathrm{g} / \mathrm{ml})$, protein $(396 \mu \mathrm{g} / \mathrm{ml})$, free amino acids $(198 \mu \mathrm{g} / \mathrm{ml})$ and secondary metabolites such as tannins $(67.5 \mu \mathrm{g} / \mathrm{ml})$, phenolic $\quad(42.5 \mu \mathrm{g} / \mathrm{ml}), \quad$ flavonoids $(82 \mu \mathrm{g} / \mathrm{ml})$, alkaloids, glycosides, thiols [13].

\section{Traditional uses and medicinal uses:}

Branches of tree are used as fodder for goats and cattle [14]. The dried twigs, logs and branches are largely used as fuel, their wood is highly valued to prepare furniture like tables, bed poles and used for house building material as poles [15]. Timber is used for agricultural implements and wheels. Spent chips are left over after extraction of Katha and cutch can be used to manufacture hardboards. Cutch is isolated from the heartwood, which is marketed as a solid extract and is used locally to $\tan$ leather. Catechu extract is 
also used for dyeing silk, cotton, canvas, paper and leather to a dark-brownish colour [14]. Branches are used for fencing purpose by the farmers to protect agricultural fields and local grasslands from domestic livestock and wild animals [15]. Acacia catechu has reported to have various medicinal properties which include immune-modulatory, hypoglycaemic, antimycotic, antifungal, antiviral, antibacterial, anti-inflammatory and antioxidant activities [16-18].

Leaves have Hepatoprotective, Antisecretory, Anti-ulcer, Antioxidant, Antibacterial, Anti-mycotic activity and also leaves grounded into fine paste is used for mitigating the intensity of headache [19]. Seeds of this plant have also been reported to have antibacterial activity. Bark possesses antifungal, antimicrobial, antiinflammatory, and antioxidant activity. Bark is often used to reduce inflammations, sooth the digestive system, mitigate skin rashes, oral use, ailments of the respiratory, digestive tracts and urinary disorders are relieved [14]. The decoction of bark mixed with milk is used to treat cold and cough also used either alone or in combination with opium to cure severe diarrhoea [15]. Fiber is helpful in increasing the levels of the good cholesterol, HDL (high density lipoprotein) in the body. It possesses unique characteristic of detoxifying the body. The fiber binds itself with the toxins and gets rid of them in the form of waste matter (www.diethealthclub.com) .

Heartwood is known to have antidiarrhoeal, anti-oxidant, anti-bacterial, antimycotic, used to treat mouth sore, gingivitis, dental caries properties [19] (Lakshmi et al. 2011). Decoction of Heartwood is prepared by boiling it with other ingredients and it is taken as tea by pregnant ladies to warm their body during pregnancy. It also cures fever during cold and provides strength to the body also help in secretion of milk [15].

\section{B. Acacia polyacantha}

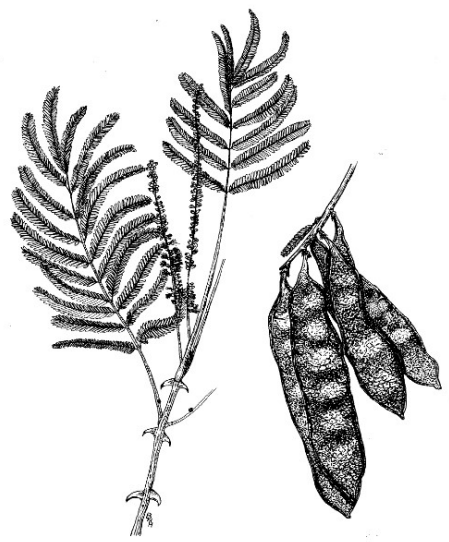

Figure 2

Acacia polyacantha is of Fabaceae family a group of plants called campylacantha [20].

Acacia polyacantha also known as Afrikaans (witdoring), English (white thorn tree, African catechu tree), Arabic (Kakamut), Bemba (Munganunshi), Lunda (Chombwe), Tongan (Mambu), Nyanja (Nyowe).Acacia polyacantha is a widely distributed in wooded grassland, deciduous woodland and bushland, riverine and 
ground water forests in altitudes up to 1800meter [21].

\section{Botanical description \& Phytochemical properties:}

Acacia polyacantha is a medium sized tree between 3.5-20meter in height. The bark of Acacia polyacantha is yellow-brown, thick peeling, trunk with fissured bark and knobby persistent prickles in pairs just below the nodes [22]. The branches are covered with silvery hairs and the whole tree is covered with brown to black thorns in pairs. The leaves are fairly large with 1435 pairs of pinnae and 20-60 leaflets of pinna. The upper surface of leaves is darker and mostly with hairs on the margins and on the leaf stalk which is 5-4 cm long [23] (A. O. Okpanachi et al. 2010). The flowers appear yellowish-white, sessile from September to December. Fruit straight, brown, flat pod, rarely tuberculous, 7-18 x $2.1 \mathrm{~cm}$ long, seed 9.7 x $6.8 \mathrm{~mm}$, compressed, central areole 3-4 x 2.5-3.5 $\mathrm{mm}$ [21]. Shivanikagra conducted phytochemical analysis of Acacia polyacantha and identified the presence of phytochemicals such as Sitosterol, Alkaloid diaboline, Anthocyanins, Catechic tannins, Flavonoids, Galactose, Mannose, Mucilage's, Oleanolic acid, Sterols, Terpenes, Reducing compounds, Saponins, Stigmasterol [23].

\section{Medicinal uses:}

Acacia polyacantha has reported various medicinal activity which include anticancer, anti-fungal, anti-crustacean, antivenin, antimalarial, anti-atherosclerotic effect, anti-inflammatory properties [24] (CSIR, 1985). The bark possesses anticancer, insecticide and astringent properties and also is used as blood purifier [24]. The bark is used in tanning. Dry powder of bark is applied externally in ulcers and Decoction used as a gargle in sore throat and toothache [23]. The decoction of the bark is used to treat leprosy, pneumonia, malaria, gonorrhoea, diabetes and believed to be aphrodisiac $[\mathbf{2 5}, \mathbf{2 6}]$. The seeds are reported to have hypoglycaemic effect [27].Root are reported to be used as antifungal, antivenin, anti-crustacean, stimulant [22]. Leaves used as an astringent, remedy for diarrhoea and dysentery [23]. It is also reported to be used as insecticide, aphrodisiac, antimalarial, antifungal and in the treatment of sores, abscesses and asthma [24, 28].

\section{Acacia Leucocephala}

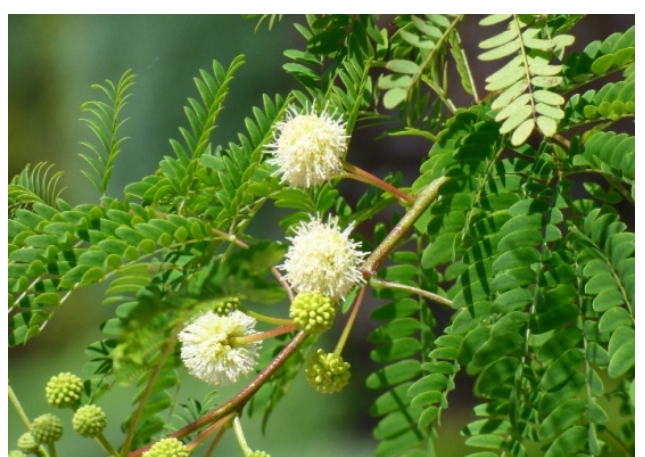

Figure 3 
Leucaena Leucocephala belongs to the family Fabaceae and is a small, fast growing tree. The specific name 'Leucocephala' came from 'Leu' meaning white and 'cephala' meaning head referring to the flower. In India, it is popularly known as Kubabul or Subabul [29]. $L$. leucocephala was known as "miracle tree" because of its worldwide success as a longlived and highly nutritious forage tree used to produce firewood, timber, green manure, shade, human food, and also to control soil erosion [30].

Leucaena Leucocephala commonly known as White popinac, Jumbay and Wild Tamarind [31]. Tan tan tree (Dutch Caribbean), Leucaena, ipil-ipil (philippines), lamtora/ -o(Indonesia), Guaje, Yaje, Unaxin (Latin America), Lead tree.

\section{Botanical description \& phytochemical properties:}

leucocephala leaves represent compound pinnate, pinnular rachis are about 5 to 10 $\mathrm{cm}$ in length and 9 to 20 pairs of leaflets contained bipinnate with 6 to 8 pairs pinnae. lanceolate are linear 2-4.5 mm wide and 8 to $15 \mathrm{~mm}$ in length. Environment factors such as water shortage, cold results in folding of leaves [32]. The bark of the young branches is smooth, grey-brown, salon pink older branches are darker greybrown and less smooth with sallow rusty orange-brown vertical cracks with a deep red inner bark (cnsi.nl).L. leucocephala species are polyploid $2 \mathrm{n}$ representing 104 chromosome. Axillary are present on stalks, display white colour their inflorescence globose is in range of 12 to $20 \mathrm{~mm}$ in diameter and 2 to $3 \mathrm{~cm}$ peduncle length. Fruit pods have raised borders when they mature become dark Brown, flat 10 to $15 \mathrm{~cm}$ long and 1.6 to $2.5 \mathrm{~cm}$ in width. Legumes contain flat 15 to 20 brown seeds [33, 34]. Phytochemical studies of $L$. Leucocephala described the presence of various secondary metabolites for example Glycosides, saponins, Tannins, flavonoids [30]. Oxalic acid and tannins are present in seeds [35, 36] (Padmavathy at al, 1987).

\section{Traditional uses and medicinal uses:}

Almost every part of the L. leucocephala speciesis utilized by humans as edibles. In the Philippine Islands, roasted seeds are used as a substitute for coffee. The young dry seeds are popped like popcorn. In Indonesia, Thailand, and Central America, people eat the young leaves, flowers, and young pods in soups [37]. The leaf has been reported to be used in poultry diets [38]. The effect of leaf has been reported on egg production and egg quality in laying hens [39]. Leaves of L. Lucocephala have been used in feed for non- ruminants like pig. It is reported to have a very good effect on the performance of growing fattening pigs [40] (Lee PK et al. 1983). Also leaves, pods and bark are used to prepare natural 
dye (Red, brown, black) in leather and cotton industries [41] (Shrivastava VS.2012). Wood are of medium density, textured and easily workable for variety of carpentry purposes like sawn timber, mine props, furniture and parquet flooring, pulp is used in paper and rayon industries [42]. Gum arises from leucaena stems and it has commercial value. The leaves, root, wood of L.leucocephala is used in agricultural purpose. Root nodules fix $500 \mathrm{~kg}$ atmospheric nitrogen annually [35]. Seed oil is used as bio fuel in diesel engines was found to involves no harmful agents. Medicinally it has been reported to have antimicrobial, antibacterial, antimicrobial, antibacterial, anti-proliferative and antidiabetic, cancer preventive, diuretic, antioxidant, anti-inflammatory, antihistaminic, pesticide, hypo-cholesterol emic properties $[31,37]$. Seed extracts have antioxidant activity due to the phenolic content. it can affect renal function by reducing the levels of albumin, ALP (alkaline phosphatase) and total protein [43] seed have antidiabetic activity used to treat Type-2 diabetes [44] (Joshi et al.2003) also used to control stomachache, as contraception and abortifacient. The seed gum used as a binder in tablet formulation $[45,46]$. Leaves used as herbal bath to cleans the body. Leaves paste is applied to poisonous bites and stings. In Malaysia, Thin paste of young leaves with rice applied around the neck to treat cough. It is also rubbed to whole body to treat measles. Leaves possess many biological properties such as antimicrobial, anticancer, cancer preventive, diuretic, anti-inflammatory, antioxidant, antitumor, antihistaminic, nematicide, pesticide, antiandrogenic, hypo-cholesterol emic and hepatoprotective [37]. Shoots boiled with alum and the water used to clean the affected part of shingles. Bark is eaten for internal pain.

\section{Acacia sinuata}

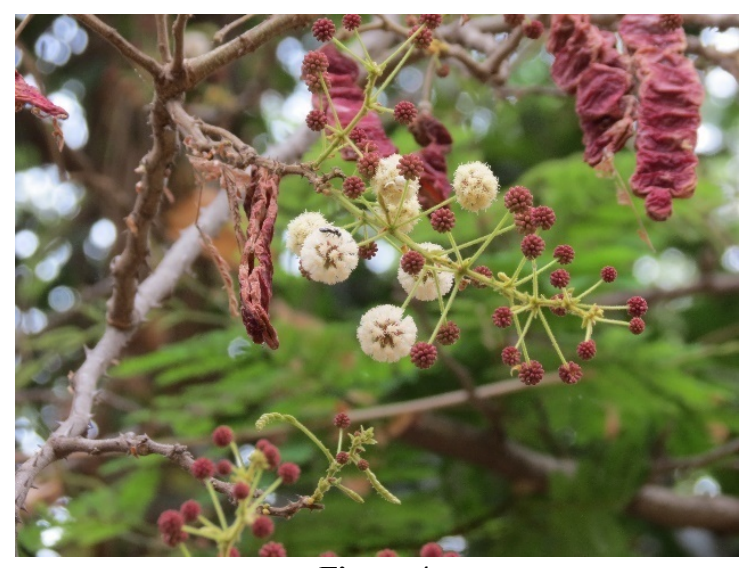

Figure 4

Acacia sinuata belongs to Fabaceae family and Mimosoideae subfamily. Acacia sinuate (Lourr.) Merr is a common prickly, scandent shrub, with internodal thorns hooked, occurring in tropical jungles throughout India, especially in the Deccan [47] (CSIR, 2003). Acacia sinuata is commonly known as Shikai, Shikaya, Chikaka, Shikakai, Banritha, Reetha, Kochi, Ritha, Sige. Acacia sinuata is a perennial, woody, large climbing shrub which grows on big trees and most well- 
known for the natural shampoo derived from its fruit [48].

\section{Botanical description and Phytochemical properties:}

Acacia sinuata found in tropical regions of India a climbing plant it is a shrub in which thorns are present at internode. Leaves are bipinnate in which the pinnae are in the pairs of 5 to 7 and up to 20 to 25 pairs of leaflets and their stalks are 1 to $1.5 \mathrm{~cm}$ in length also contains thorny and velvety ranchis, pinnae are in the shape of oblonged lanced very pointed and 3 to $10 \mathrm{~mm}$ in length. Branches are thorny has broad base and short. When flower gets mature the size of its axillary head is around $1 \mathrm{~cm}$ they are pink to yellow. Fruits and flowers are observed in the months of sept and march. Pods are thick flattened stalked wrinkled and depressed between seeds. $8 \mathrm{~cm}$ in length and $1.5 \mathrm{~cm}$ in width these plants are propagated by seeds [49-52]. Thube Smita conducted phytochemical analysis of Acasia Sinuata which contains alkaloids, sterols, glycosides, flavonoids, saponins, tannis, proteins, amino acids, and reducing sugars [47].

\section{Medicinal uses}

Acacia sinuata has wide range of medicinal property known for its anti-inflammatory properties used to treat malarial infections jaundice. Helps to prevent the clotting of blood as well as used to cure disease specific for liver. Utilized to cure skin sensational burnings, vitiligo, constipation eczema. the immunosuppressant property of seeds is due to the presence of lactam (CSIR, 2000).

\section{CONCLUSION}

Species of genus acacia has been use since ancient time to treat various diseases in traditional system medicine. The selected plants (Acacia polyacantha, Acacia catechu, Acacia Leucocephala, Acacia sinuata) are source of secondary metabolite i.e. alkaloids, flavonoids, terpenoids, tannin etc Experimental studies have proven it's antibacterial, antifungal, antidiabetic, antiinflammatory, antihypertensive, antiplasmodic, antioxidant activity due to presence of secondary metabolite.

Nowadays the contribution of rural communities in forest resources management begins to appear as an inevitable element in the forest resources management strategies. Conservation and management of natural species of Acacia genus is essential in environment stabilisation and fighting against drought.

\section{REFERNCES}

[1] Gould IM, Bal AM. New antibiotic agents in the pipeline and how they can help overcome microbial resistance. Virulence. 2013;4(2):185-91.

[2] Sieradzki K, Roberts RB, Haber SW, Tomasz A. The development of vancomycin resistance in a 
patient with methicillin-resistant

Staphylococcus aureus infection.

New England Journal of Medicine. 1999;340(7):517-23.

[3] Arunkumar S, Muthuselvam M. Analysis of phytochemical constituents and antimicrobial activities of Aloe vera L. against clinical pathogens. World Journal of Agricultural Sciences. 2009;5(5):572-6.

[4] Aneesh T, Hisham M, Sekhar S, Madhu M, Deepa T. International market scenario of traditional Indian herbal drugs-India declining.... International Journal of Green Pharmacy (IJGP). 2009;3(3).

[5] Krishnaiah D, Sarbatly R, Bono A. Phytochemical antioxidants for health and medicine a move towards nature. Biotechnology and Molecular Biology Reviews. 2007;2(4):97-104.

[6] Malviya S, Rawat S, Kharia A, Verma M. Medicinal attributes of Acacia nilotica Linn.-A comprehensive review on ethnopharmacological claims. International Journal of Pharmacy \& Life Sciences. 2011;2(6).

[7] Joy P, Mathew S, Skaria BP. Kerala Agricultural University Aromatic and Medicinal Plants
Research Station Odakkali. Asamannoor PO Ernakulam District, Kerala, India. 1998.

[8] Kalaivani T, Mathew L. Free radical scavenging activity from leaves of Acacia nilotica (L.) Wild. ex Delile, an Indian medicinal tree. Food and Chemical Toxicology. 2010;48(1):298-305.

[9] Seigler DS. Phytochemistry of Acacia—sensu lato. Biochemical systematics and ecology. 2003;31(8):845-73.

[10] Hashmat MA, Hussain R. A review on Acacia catechu Willd. Interdisciplianary Journal of Conter Mporary Research in Business. 2013;5:21-8.

[11] Stohs SJ, Bagchi D. Antioxidant, anti-inflammatory, and chemoprotective properties of Acacia catechu heartwood extracts. Phytotherapy Research. 2015;29(6):818-24.

[12] Saini ML, Saini R, Roy S, Kumar A. Comparative pharmacognostical and antimicrobial studies of acacia species (Mimosaceae). Journal of Medicinal Plants Research. 2008;2(12):378-86.

[13] Ramesh B, Jayabharathi V. Phytochemical Screening, HPTLC and GCMS Profile of Acacia 
catechu (Lf) Willd Hydroethanolic

Leaf Extract. Int J Curr Microbiol App Sci. 2017;6(1):82-94.

[14] Hocking D. Trees for drylands Oxford. IBH Publishing Co. Pvt. Ltd., New Delhi; 1993.

[15] Singh Kn. Vaiation Studies On Katha Content In Relationto Different Forms Of Thair (Acacia Catechu Willd.) Trees: College Of Forestry Dr. Yashwant Singh Parmar University Of Horticulture And ...; 2000.

[16] Singh K, Mittal R, Barthwal K. Hypoglycaemic activity of Acacia catechu, Acacia suma, and Albizzia odoratissima seed diets in normal albino rats. The Indian journal of medical research. 1976;64(5):754.

[17] Ray D, Sharatchandra K, Thokchom I. Antipyretic, antidiarrhoeal, hypoglycaemic and hepatoprotective activities of ethyl acetate extract of Acacia catechu Willd. in albino rats. Indian Journal of Pharmacology. 2006;38(6):408.

[18] Wang Y-H, Wang W-Y, Chang CC, Liou K-T, Sung Y-J, Liao J-F, et al. Taxifolin ameliorates cerebral ischemia-reperfusion injury in rats through its antioxidative effect and modulation of
NF-kappa B activation. Journal of biomedical science. 2006; 13(1): $127-41$

[19] Lakshmi $T, \quad$ Rajendran $R$. Estimation of biomarker epicatechin in ethanolic bark extract of Acacia catechu willd by HPLC method. Journal of Pharmaceutical Sciences and Research. 2012;4(3):1764.

[20] Palgrave KC. Palgrave's Trees of Southern Africa: Penguin Random House South Africa; 2015.

[21] Orwa C, Mutua A, Kindt R, Jamnadass R, Anthony S. Agroforestree Database: a tree reference and selection guide version 4.0. World Agroforestry Centre, Kenya. 2009;15.

[22] Kirtikar KR, Basu BD. Indian medicinal plants. Indian Medicinal Plants. 1918.

[23] Deshmukh S, Shrivastava B, Bhajipale N. A Review on Acacia species of therapeutics importance. International Journal of Pharmaceutical and Biological Science Archive. 2018;6(04).

[24] Van Puyvelde L, Geysen D, Ayobangira F-X, Hakizamungu E, Nshimiyimana A, Kalisa A. Screening of medicinal plants of Rwanda for acaricidal activity. 
Journal of Ethnopharmacology. 1985;13(2):209-15.

[25] Hedberg I, Hedberg O, Madat PJ, Mshigeni KE, Mshiu E, Samuelsson G. Inventory of plants used in traditional medicine in Tanzania. II. Plants of the families Dilleniaceae-Opiliaceae. Journal of Ethnopharmacology. 1983;9(1):105-27.

[26] Gessler M, Nkunya $\mathrm{MH}$, Mwasumbi LB, Heinrich M, Tanner M. Screening Tanzanian medicinal plants for antimalarial activity. Acta tropica. 1994;56(1):65-77.

[27] Gandhi P. A new proanthocyanidin from the stem bark of Acacia suma. Experientia. 1977;33(10):1272-.

[28] Massele A, Nshimo C. Brine shrimp bioassay for biological activity of medicinal plants used in traditional medicines in Tanzania. East African medical journal. 1995;72(10):661-3.

[29] Rao TC, Lakshminarayana G, Prasad N, Rao SJM, Azeemoddin G, Ramayya DA, et al. Characteristics and compositions ofCarissa spinarum, Leucaena leucocephala and Physalis minima seeds and oils. Journal of the
American Oil Chemists Society. 1984;61(9):1472-3.

[30] Brewbaker J, Sorensson C. Leucaena: new tree crops from interspecific hybrids. Advances in new crops. 1990:283-9.

[31] Meena Devi V, Ariharan V, Nagendra Prasad P. Nutritive value and potential uses of Leucaena leucocephala as biofuela mini review. Research Journal of Pharmaceutical, Biological and Chemical Sciences. 2013;4(1):515-21.

[32] Duke JA. Handbook of energy crops. Handbook of Energy Crops. 1983.

[33] Little EL, Wadsworth FH. Common trees of Puerto Rico and the Virgin islands: US Department of Agriculture, Forest Service; 1964.

[34] Stevens WD, Ulloa C, Pool A, Montiel OM. Flora de Nicaragua: Missouri Botanical Garden Press St. Louis; 2001.

[35] Azeemoddin G. Jagan Mohan Rao S, ThirumalaRao SD. J Food SciTechnol. 1988;25:158.

[36] Sotolu A. Growth performance of Clarias gariepinus (Burchell, 1822) fed varying inclusions of Leucaena leucocephala seed meal. Tropicultura. 2010;28(3):168-72. 
[37] Zayed MZ, Samling B. Phytochemical constituents of the leaves of Leucaena leucocephala from Malaysia. Int J Pharm Pharm Sci. 2016;8(12):174-9.

[38] D'Mello J, Taplin D. Leucaena leucocephala in poultry diets for the tropics. World Rev Anim Prod. 1978;14(03):41-7.

[39] Atawodi S, Mari D, Atawodi J, Yahaya Y. Assessment of Leucaena leucocephala leaves as feed supplement in laying hens. African Journal of Biotechnology. 2008;7(3):317-21.

[40] Solanki VK, Parte V, Sharma R, Khan I. PRO TEIN RICH FOD DER TREE-LEUCAENA

\section{LEUCOCEPHALA.}

[41] Badal S. Compositions and Physico-chemical characteristic of Leucaena leucocephala (Subabul). International Journal of Research in Engineering and Applied Sciences. 2017;7(6):199-202.

[42] Alabi D, Alausa A. Evaluation of the mineral nutrients and organic food contents of the seeds of Lablab purpureus, Leucaena leucocephala and Mucuna utilis for domestic consumption and industrial utilization. World Journal of Agricultural Sciences. 2006;2(1):115-8.
[43] Chowtivannakul P, Srichaikul B, Talubmook C. Antidiabetic and antioxidant activities of seed extract from Leucaena leucocephala (Lam.) de Wit. Agriculture and Natural Resources. 2016;50(5):357-61.

[44] Raman K, Rana A, Sharma A. Phytochemical analysis \& anthelmintic activity of leaves of leucaena leucocephala. World Journal of Pharmaceutical Research. 2018;7(11):24.

[45] Deodhar U, Paradkar A, Purohit A. Preliminary evaluation of Leucaena leucocephala seed gum as a tablet binder. Drug development and industrial pharmacy. 1998;24(6):577-82.

[46] Verma P, Razdan B. Studies on disintegrant action of Leucaena leucocephala seed gum in ibuprofen tablet and its mechanism. 2007.

[47] Smita T, Samrana BR, Ali GMS. Preliminary Phytochemical Screening and Anthelmintic Activity of Acacia sinuata (Lourr.) Merr against Intestinal Helminthiasis. Research Journal of Pharmacy and Technology. 2011;4(5):756-8.

[48] Vijayasekhar V, Prasad MS, Joshi DS, Narendra K, Satya AK, Rao 
KS. Evaluation of Phytochemicals

and in vitro Pharmacological

Activity of Acacia sinuata Plant

Leaves. International Journal of

Pharmaceutical Sciences and

Research. 2016;7(6):2423.

[49] Pullaiah T. Medicinal Plants in India, Vol. 1. New Delhi: Regency Publication. 2002.

[50] Acacia And Health., http://www.diethealthclub.com/her bs-andnatural-cures/acacia.html

[51] A.O. Okpanachi, A.B. Adelaiye, A.A.U. Dikko, M. Kabiru, A. Mohammed and Y. Tanko
Evaluation of the Effect of Aqueous methanolic Stem Bark Extract of Acacia polyacanthaon Blood Glucose Levels of Alloxan Induced Diabetic Wistar Rats International Journal of Animal and Veterinary Advances 2(3): 5962,2010

[52] Anonymous. The Wealth of India. CSIR: New Delhi. Vol- I. 1985. p. 42. 